\title{
Blaze Manufacturing: An Ethical Analysis
}

\author{
Wanda K. Causseaux, DBA, CMA, Siena College, USA
}

A. Bruce Caster, Ph.D., CGMA, Utica College, USA

\begin{abstract}
Students frequently have difficulty systematically analyzing ethical situations. They tend to respond to situations by indicating that a particular action is "just not right." This case uses the IMA Statement of Ethical Professional Practice as a framework for analyzing and resolving ethical conflict. The case is based on cost/managerial accounting and is appropriate for late in a managerial accounting course or early in a junior level cost accounting course. The case involves cost analysis, and it examines gross margin versus contribution margin as tools for analyzing product profitability. It also challenges the student to examine the behavior of several of the main characters from an ethical point of view and to examine pathways for resolving ethical conflicts. Suggested solutions, additional discussion, and teaching notes are provided. The story is based on a real situation with a privately held company. Details have been changed to protect the identity of the persons and companies involved.
\end{abstract}

Keywords: Ethical Conflict; Cost Accounting; Cost Analysis

\section{INTRODUCTION}

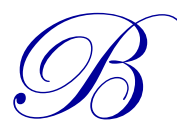
laze Manufacturing is a small, closely-held textile manufacturing operation located in upstate New York. They make textile products such as bedspreads and curtains for institutional customers, primarily hotels and hospitals. Textile manufacturing in the US is a tough business. Foreign producers are able to pay lower wages and are exempt from many of the environmental and safety regulations which impose additional costs on domestic companies. The result has been strong price competition that has driven many US manufacturers completely out of business. Though Blaze has managed to stay in business, it has struggled with profitability in recent years. It recently lost a number of long-standing customers to foreign competitors, and management is very concerned that Blaze may not show a profit in the current year.

Blaze Manufacturing operates as a job shop, and it does not mass produce inventory items for sale through normal retail channels. Instead, Blaze focuses on producing goods to fill specific orders received from individual customers. Blaze's products have relatively standard layouts: bedspreads in king, queen, and double sizes, and curtains to fit various standard-sized windows. However, each customer chooses the fabrics, the colors, and the styles that go into making the items it orders. Customers can also request other customizations, such as items made in non-standard sizes.

Joe has been president of Blaze since it was founded 20 years ago, and Bill, the lead salesman, joined the company a year later. As president, Joe is paid a salary plus an annual bonus which is based on the company's sales revenue. Bill is paid only a small salary; most of his compensation comes from sales commissions which are four percent of the gross revenue from his sales. The previous company controller, Mike, retired at the beginning of the current year. Wendy is filling in as temporary controller until a permanent replacement can be found.

George and several members of his family are in the "turnaround" business, that is, they invest in troubled companies, restore them to profitability, and then sell their investments at a substantial profit. George and his family currently own a significant amount of stock in Blaze Manufacturing. George created Omega Consulting Partners to help him manage his portfolio of investments. In addition to managing George's investments, Omega also provides consulting and management advisory services, but only to companies in which George has invested.

Wendy is employed by Omega as a financial and management consultant. She has a bachelor's degree in Accounting, she holds a CMA certificate, and she has previous manufacturing experience. George felt that Wendy's 
background made her a perfect candidate to become Blaze's temporary controller, so he assigned her to that position.

As an employee of Omega Consulting, Wendy reports directly to George. However, she is currently assigned to be the temporary controller at Blaze Manufacturing, and in that position she reports directly to Joe. Omega Consulting bills Blaze Manufacturing for the services which Wendy provides. Thus, even though Wendy still receives her paycheck from Omega, Blaze is effectively paying Wendy's salary through the payments it makes to Omega.

\section{FACTS}

Bill recently announced that he has recruited a new, large customer and has negotiated an initial order that was very substantial. Everyone at Blaze is excited by this new order. It is normal practice at Blaze Manufacturing for the corporate controller to review all large orders, including orders which come from new customers with whom Blaze has had no experience, for profitability of the order and credit-worthiness of the customer. The controller prepares a formal profitability analysis of the order, and then that analysis is presented to the company president and the salesman who negotiated the order.

Wendy is new to Blaze Manufacturing, and in order to accurately calculate the product costs and to perform a proper profitability analysis she needs to fully understand Blaze's manufacturing process. Therefore, Wendy asked Bob, the plant manager, to give her a detailed tour of the plant. Bob is happy to oblige, and he is quite impressed that someone from the front office really wants to know how things work. He tells Wendy that he will walk her through the process of making quilted bedspreads, as this is the most complex process in the plant.

The tour begins at the receiving dock and storage area. The company stocks some items used in every bedspread such as backing (always white), the batting, and quilting thread. Other materials such as the top fabric and matching threads are purchased on a per job basis.

The first stage in the production process is quilting. The quilting machine holds two bolts of fabric and the batting. The lower bolt is the backing and the upper is the top fabric specified by the customer. The batting is in the middle. The machine has twenty needles and 20 spindles which hold the quilting thread. All bedspreads are quilted with white thread. After the quilting process, the quilted fabrics are rolled to be moved to the next stage in the process.

The next stage in the manufacturing process is cutting. Large tables are used which allow as many as ten bedspreads to be cut at a time from the quilted fabrics. Two people work in the cutting area. One is a dedicated cutter, the other is also a sewer. The sewer assists the cutter in placing and securing the fabric to be cut. Blaze employs one cutter and five sewers.

As soon as a quilted bedspread is cut, the sewer begins attaching the outer binding. Binding is made from the customer specified fabric used on the top of the spread. The sewer returns the completed bedspread to the cutting table where it is folded and shrink wrapped for shipping to the customer.

Wendy is really pleased with the tour. She asks Joe about other products and learns that Blaze also makes two types of curtains; one for hospitals and one for hotels. The manufacturing process is similar except the curtains are not quilted. Instead the sewer hems the curtains and the attaches hanging hardware.

The factory is capable of producing 80 bedspreads per day. At full capacity, another employee would be needed on the quilting machine as Bob could not run the machine and perform the necessary machine maintenance.

Based on the tour and explanations, Wendy is able to accurately attach direct costs to the bedspreads. Direct materials for bedspreads are as follows: top fabric, batting, and backing. Although thread use could be calculated and the cost assigned to specific products, it is just not efficient to do so. Therefore, the thread is treated as a variable overhead cost rather than a direct material. Direct labor consists of the cutter and the sewer. Wendy is also able to estimate variable and fixed overhead on a per unit basis. 
The cost of Bob's labor is more difficult to assign. As plant manager, Bob is paid a salary plus a contracted amount for overtime. However, Bob only spends about 40 percent of his time on activities related to managing the plant: production scheduling, supervision of employees, and the like. The other 60 percent of his time is spent running the quilting machine. Quilting seldom runs smoothly, so Bob's quilting time is usually divided between running the machine and maintaining the machine, for which he is also responsible. The proportions of his quilting time that are spent running the machine versus maintaining the machine can vary greatly. Wendy finally decides that the most practical answer is just to treat all of Bob's labor as an indirect cost.

Table 1. Profitability Analysis

\begin{tabular}{lc}
\hline Selling Price & $\$ 77.00$ \\
\hline Cost of Goods Sold & \\
Direct Materials & $\$ 67.50$ \\
Direct Labor & 5.50 \\
Variable Overhead & 2.00 \\
Fixed Overhead & 3.25 \\
\hline Total Cost Per Unit & $\$ 78.25$ \\
Gross Margin Per Unit & $\$(1.25)$ \\
\hline
\end{tabular}

Wendy's profitability analysis, presented in Table 1, shows that Bill's new order will not be profitable. The selling price won't even cover the costs. Her recommendation is that Blaze Manufacturing not accept the order unless the price is increased. Joe and Bill challenge her recommendation, arguing, "You may have had a lot of experience with large manufacturers, but you don't know the textile business and you don't know this company. We're fighting every day against low-price competitors, and if we try to raise the price we're going to lose this order." "This is a very large order, and everyone knows that if you make enough units then you'll spread out the production costs over all those units and it won't cost so much per unit. And with the revenue we're going to get from selling all those units, we're eventually going to make a profit."

The discussion goes on and on, and Wendy can't seem to find any way to persuade Joe and Bill that her profitability analysis and her recommendation are valid. She thinks, perhaps if she repeated the analysis, this time looking at contribution margin rather than gross margin on sales, then they might understand what she has been trying to explain to them.

\section{EPILOGUE}

Blaze's management rejected Wendy's recommendation and accepted the order as originally priced. In spite of the best efforts of Omega and Wendy, the management of Blaze continued to operate without significant change. Blaze was liquidated within a year.

\section{QUESTIONS}

1. Repeat the profitability analysis of this order using a contribution margin approach rather than a gross margin approach. What do the results of this new analysis reveal about this order? Do these results support Wendy's original conclusion?

2. How would you use this new information to explain further to Bill and Joe the need either to re-price or to reject this order?

3. What other financial information would be useful to enable further analysis of this order?

4. Review the IMA Statement of Ethical Professional Practice. In this case Wendy, a CMA, is the only employee bound by the ethical standards presented in that statement. However, for purposes of this question assume that it is also appropriate to use those same ethical standards to evaluate the behavior of Bill and Joe. 
a. Which (if any) of those ethical standards have Wendy, Bill, and Joe met? Indicate specifically which standards each of them may have met and which actions met those standards.

b. Which (if any) of those ethical standards have Wendy, Bill, and Joe violated? Indicate specifically which standards each of them may have violated and which actions constituted violations of those standards.

5. Using the IMA Resolution of Ethical Conflict as a guide, what recommendations would you make to Wendy?

\section{PROPOSED SOLUTIONS}

1. The contribution margin analysis, presented in Table 2, shows that this order has a negative contribution margin per unit. That is, at the current selling price the variable cost per unit exceeds the selling price per unit. These results are consistent with Wendy's original conclusion: This order will not be profitable.

Table 2. Profitability Analysis Based on Contribution Margin

\begin{tabular}{lc}
\hline Selling Price & $\$ 77.00$ \\
\hline Variable Cost Per Unit & \\
Direct Materials & $\$ 67.50$ \\
Direct Labor & $\$ 5.50$ \\
Variable Overhead & $\$ 2.00$ \\
$\quad$ Sales Commissions (4 percent of selling price) & $\$ 3.08$ \\
\hline Variable Cost Per Unit & $\$ 78.08$ \\
Contribution Margin Per Unit & $\$(1.08)$ \\
\hline
\end{tabular}

2. Accepting this order at the current price will reduce Blaze's overall profits. An unprofitable order like this one should either be re-priced (to be profitable) or rejected.

3. No other financial information would be useful in further analyzing this case. In fact, no further analysis is needed: An order with a negative contribution margin reduces the company's overall profitability and under normal circumstances should not be accepted.

4. a. Wendy has taken numerous actions that meet the IMA standards.

- Competence: The first responsibility in the competence standard is to maintain appropriate professional expertise. Wendy has an appropriate level of education and experience for the job she is doing. In addition, she is also continually developing her knowledge and skills by learning about the manufacturing process.

- Competence: The third responsibility in the competence standard is to provide decision support information. Wendy is providing timely decision support and recommendations with the order cost analysis.

- Credibility: The first responsibility in the credibility standard is communication. Wendy has communicated information fairly and objectively.

- Credibility: The second responsibility is to disclose relevant information. Wendy is meeting this responsibility by providing the cost analysis for management to make a decision regarding the order.

- Credibility: The third responsibility is to make disclosures. At the end of the case, Wendy is deciding how to further handle the situation. In order to meet the third responsibility in Credibility, she must report to the owners the potential for losses if the order is accepted by the company. 
Joe and Bill have taken no actions that indicate their compliance with any of the standards.

b. Joe has taken numerous actions that violate the IMA standards.

- Competence: The first responsibility in the competence standard is to maintain appropriate professional expertise. It is clear from the case that Joe has some level of understanding of accounting and the cost structure of his company. However, his insistence on the profitability of the order without a contribution margin analysis indicates a weakness in his knowledge.

- Competence: The second responsibility of competence is to meet technical standards. Dismissing the profitability analysis without an alternative explanation is indicative of lack of technical understanding.

- Competence: The third responsibility of competence is to provide accurate decision support. Accepting a large order based on flawed cost understanding violates this standard.

- Integrity: The first responsibility in the integrity standard is to eliminate conflicts of interest. Joe and Bill are more interested in the sales than in truly understanding the profitability of the company. This action indicates that they are pushing for this order and for their bonus/ commission rather than the long-term viability of the company.

- Integrity: the second responsibility of integrity is to refrain from engaging in activities that would prejudice carrying out duties ethically. Joe's continued support of the unprofitable order and lack of recognition of the conflict of interest is causing him to be in violation of this standard.

Bill has violated the same standards.

Wendy has taken no action in violation of the standards.

5. The answers will vary for the individual students, but in general they should all consider these elements:

1) The first step for resolving ethical conflicts is to follow "your organization's established policies the resolution of such conflicts." Wendy works for Omega, but Omega has assigned to her provide support to the management of Blaze. And in the context of that assignment, she reports to Joe, the President of Blaze. That does raise questions about whose policies she should follow, Omega's or Blaze's. However, since there is no indication that either organization has any policies on resolving ethical conflicts, that first step does not appear to be available anyway. The second step would for Wendy to discuss the issue with her immediate supervisor, except when it appears that the supervisor is involved. Again, one needs to ask which supervisor in which organization is the relevant person to discuss the issue with. Her supervisor at Blaze is Joe, and Joe is definitely involved in the problem. And there is no one at any higher level within that organization to discuss it with. Wendy's supervisor at Omega is George. Although the ethical issue is related to Blaze, since Blaze has engaged Omega to provide Wendy's services to Blaze, it would be appropriate for Wendy to discuss this issue with George. If that does not resolve the issue, then next step would be to discuss the issue with supervisors at higher levels within the organization, including if necessary, the board of directors. However, both organizations are small and privately-held, and neither one has an active board of directors, so this step also does not appear to be available to Wendy.

2) Since the other channels for resolving this issue appear to be unavailable, it is possible that Wendy may have to seek advice from an IMA Ethics Counselor.

3) As a last resort, Wendy may need to consult her own attorney to clarify how to proceed from here. 


\section{TEACHING NOTES}

\section{Contribution Margin Approach}

The students should already be familiar with this approach from having studied it previously. However, it might be useful to see if you can spark some discussion by pointing out that, unlike gross margin, contribution margin ignores the fixed manufacturing costs. And then ask them why. See if you can lead them into discovering that total fixed costs will not change, whether or not this order is accepted, and the fact that fixed costs will not change makes them irrelevant.

A second discussion point is the role that variable costs play in the decision process. This is a good opportunity to remind students that variable operating costs are included in contribution margin analysis. However, the case deliberately only mentions one variable operating cost: sales commissions. It is only mentioned early in the case and not all students will identify that subtle, yet important detail. Many students will want additional financial information. There are no other relevant variable costs for this analysis.

Finally, students must understand that, to the extent that costs change as a result of this order, the additional revenue from the order must cover those additional costs. The claim that Joe and Bill make that the manufacturing overhead will be spread out over more units, eventually making the order profitable, is invalid. Since the order has a negative contribution margin, selling more units will only increase the losses to the company.

\section{Facts Versus Conclusions Versus Opinions}

Another useful exercise is to ask students to summarize the facts of the case. It may seem to be a trivial exercise, but we have found that students frequently have a difficult time distinguishing facts ("Joe wants to accept this order.") from conclusions ("Joe is so eager to earn his bonus that he does not care whether or not this order will be profitable.") from opinions ("Joe's actions are unethical."). We consider it worthwhile to spend some time on this exercise in an effort to build the students' skills in identifying facts and separating them from conclusions and opinions.

\section{AUTHOR BIOGRAPHIES}

Dr. Causseaux is an Assistant Professor of Accounting at Siena College in Loudonville, NY. She teaches Financial, Managerial, and Cost Accounting, Honors Managerial Accounting, and Fraud and Forensic Accounting. She is a member of the IMA, the AAA, and the ACFE. She spent 14 years in manufacturing and commercial banking.

Dr. Caster is an Associate Professor of Accounting at Utica College in Utica, NY, where he teaches Financial Accounting, Managerial Accounting, Accounting Information Systems, Auditing, and Accounting Theory. He is a member of the AICPA, the AAA, the Georgia Society of CPAs, and the ACFE.

Additional Resources: Students may want some help with the technical aspects of the accounting. They may also want to explore more about the codes of professional ethics. Many textbooks on Managerial and Cost Accounting would appropriate. The following references could be used:

\section{REFERENCES}

Edmonds, Tsay, Olds (2015). Fundamental Managerial Accounting Concepts, $7^{\text {th }}$ Ed. McGraw-Hill Irwin. Garrison, Noreen, Brewer (2015). Managerial Accounting $15^{\text {th }}$ Ed. McGraw-Hill.

Horngren, Datar, Rajan (2015). Cost Accounting, $15^{\text {th }}$ Ed. Pearson.

Institute of Management Accountants. http://www.imanet.org/resources-publications/ethics-center

Association of Certified Fraud Examiners. http://www.acfe.com/code-of-ethics.aspx

American Institute of Certified Public Accountants.

http://www.aicpa.org/Research/Standards/CodeofConduct/Pages/default.aspx

http://www.aicpa.org/interestareas/professionalethics/resources/pages/default.aspx 